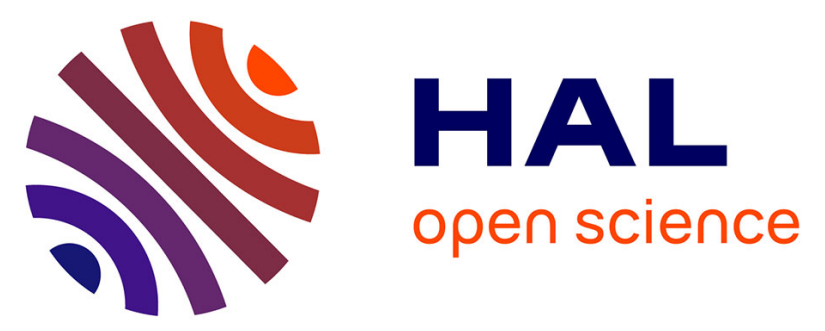

\title{
Confinement and Time Immemorial: Prebiotic Synthesis of Nucleotides on a Porous Mineral Nanoreactor
}

Francisco Rodrigues, Thomas Georgelin, Guillaume Gabant, Baptiste Rigaud, Fabrice Gaslain, Guanzheng Zhuang, Maria Gardênnia da Fonseca, Valentin Valtchev, David Touboul, Maguy Jaber

\section{To cite this version:}

Francisco Rodrigues, Thomas Georgelin, Guillaume Gabant, Baptiste Rigaud, Fabrice Gaslain, et al.. Confinement and Time Immemorial: Prebiotic Synthesis of Nucleotides on a Porous Mineral Nanoreactor. Journal of Physical Chemistry Letters, 2019, 10 (15), pp.4192-4196. 10.1021/acs.jpclett.9b01448 . hal-03039978

\section{HAL Id: hal-03039978}

\section{https://hal-normandie-univ.archives-ouvertes.fr/hal-03039978}

Submitted on 4 Dec 2020

HAL is a multi-disciplinary open access archive for the deposit and dissemination of scientific research documents, whether they are published or not. The documents may come from teaching and research institutions in France or abroad, or from public or private research centers.
L'archive ouverte pluridisciplinaire HAL, est destinée au dépôt et à la diffusion de documents scientifiques de niveau recherche, publiés ou non, émanant des établissements d'enseignement et de recherche français ou étrangers, des laboratoires publics ou privés. 


\section{Confinement and Time Immemorial: Prebiotic Synthesis}

\section{of Nucleotides on a Porous Mineral Nanoreactor}

Francisco Rodrigues, ${ }^{a, b, *}$ Thomas Georgelin, ${ }^{c}$ Guillaume Gabant,${ }^{c}$ Baptiste Rigaud, ${ }^{d}$ Fabrice Gaslain, ${ }^{e}$ Guanzheng Zhuang, ${ }^{a}$ Maria Gardênnia da Fonseca, ${ }^{f}$ Valentin Valtchev ${ }^{g}$, David Touboul ${ }^{h}$ and Maguy Jaber $^{a, *}$

a Sorbonne University, CNRS UMR 8220, Laboratoire d'Archéologie Moléculaire et Structurale, 4 place Jussieu, F-75005 Paris, France.

b Department of Chemistry, State University of Paraiba, UEPB, Campina Grande, Paraíba, Brazil.

c Centre de Biophysique Moléculaire, CNRS, Rue Charles Sadron, 45000 Orléans, France.

${ }^{d}$ CNRS Institut des Matériaux de Paris Centre (FR2482), 4 place jussieu, 75005 Paris, France.

e MINES ParisTech, PSL - Research University, MAT - Centre des matériaux, CNRS UMR 7633, BP 87, F-91003 Evry, France.

${ }^{f}$ Department of Chemistry, Federal University of Paraíba, UFPB, João Pessoa, Paraíba, Brazil.

g Normandy University, Laboratoire Catalyse \& Spectrochimie, ENSICAEN, 6 bl Maréchal Juin, 14050 Caen, France.

${ }^{h}$ CNRS-Institut de Chimie des Substances Naturelles, UPR2301, Université Paris-Saclay, 91198 Gifsur-Yvette cedex, France

\section{AUTHOR INFORMATION}

\section{Corresponding Author}

maguy.jaber@upmc.fr, *francisco.rodrigues@cct.uepb.edu.br 
ABSTRACT: Here, we report the successful one-pot synthesis of adenosine mono, di and tri phosphate in the confined space of a mordenite zeolite. This is also the first report of ATP synthesized onto a porous mineral surface. The results revealed a plausible prebiotic route to ribonucleotides and highlighted the contribution of microporous minerals in the origins of life.

\section{TOC GRAPHICS}

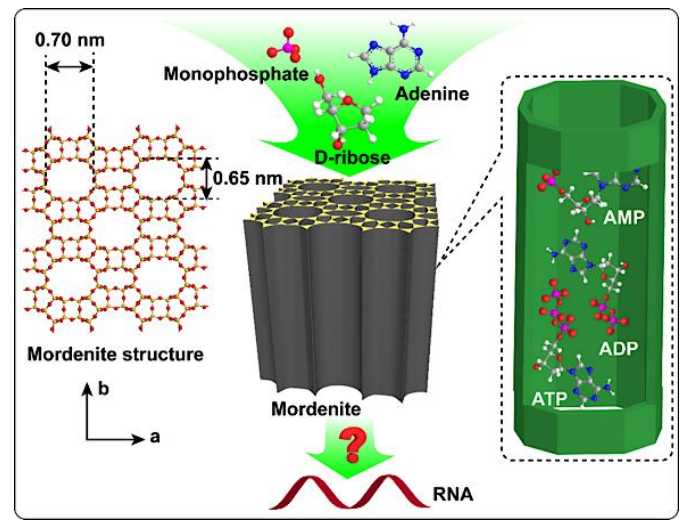

KEYWORDS: mordenite, RNA building blocks, phosphoribosyl pyrophosphate, ribonucleotides, Origins of Life. 
One of the most controversial questions in the "RNA World" hypothesis is how canonical nucleotides are synthesized on the primitive Earth, in abiotic conditions. Among prebiotic chemists, a big school assumes that RNA did not evolve as first genetic material, but was preceded by non-RNA oligonucleotides. ${ }^{1}$ On turn, nucleotides may be considered as building blocks of XNA type. From the chemical perspective, nucleotides are formed from their constituent parts: sugar, nucleobase and phosphate groups. Through some molecular evolution pathways, the organic/inorganic molecules are initially formed from simple abiotic reactants. ${ }^{2-3}$ Therefore, it is reasonable to assume that they originate from the self-assembly of such building blocks. However, both kinetic and thermodynamic considerations associated to hydrolysis reactions are the "roadblock" to long chain nucleosidepolyphosphates and the presence of any abiotic catalysts are necessary. ${ }^{2-7}$

Previous attempts in prebiotic synthesis of nucleotides is mainly under aqueous solution and uses robust pathways with a large number of intermediate reactions. However, the mineral surfaces are often considered as potential prebiotic catalysts for one-pot synthesis from its building blocks.

In the 1940s, Oparin and Bernal suggested that hydrated minerals play an important role in the origin of life. ${ }^{8-9}$ Since then, different mineral surfaces have been studied to select and concentrate key monomers from diluted solutions and promote chemical reactions on their active sites. Porous or interlayer surfaces with high hydration enthalpies may provide the driving force for condensation or polymerization reactions to form more complex biomolecules such as nucleotides and RNA. ${ }^{10-17}$ Among these surfaces, clay minerals such as montmorillonite are widely explored to explain acid-catalyzed reactions in prebiotic scenarios. They are formed by the weathering of volcanic ash deposed into ancient seas. On the other hand, crystalline microporous aluminosilicates (zeolites) exhibiting strong active sites and periodic arrangements of cages and channels with molecular dimensions that allowed them as a pertinent candidate for hydrocarbon conversion in prebiotic synthesis. Additionally, they may also 
represent one of the oldest minerals on our planet originating from silica-rich volcanic glasses which were certainly abundant in the early Earth. ${ }^{18-19}$

In the present study, we employed the synthetic counterpart of the mineral Mordenite as nanoreactor to nucleotides. Confinement, temperature and humidity were proposed to overcome thermodynamic and kinetic factors. Mordenite was selected as a mineral model because of its highly siliceous framework and large channel system. ${ }^{20}$ The highly siliceous framework offers stability under acidic conditions and the large pore $(7.1 \AA)$ system is able to accommodate relatively bulky molecules. Additionally, this zeolite can be formed under different geological conditions, and thus is largely present in the top strata of the Earth crust. ${ }^{21}$

The first step of our study includes the adsorption of adenine (A), D-ribose $(\mathrm{R})$ and monophosphate $\left(\mathrm{P}_{\mathrm{i}}\right)$ building blocks into mordenite (MOR) at $\mathrm{pH}$ 2-3. Adenine was adsorbed firstly in the pores of mordenite (A@MOR) and then D-ribose $(\mathrm{R})$ and monophosphate $\left(\mathrm{P}_{\mathrm{i}}\right)$ were added $\left(\left(\mathrm{R}+\mathrm{P}_{\mathrm{i}}\right) \mathrm{A} @ \mathrm{MOR}\right)$. For more details, please see Experimental Methods.

Nitrogen adsorption measurements revealed substantial changes in the surface characteristic of $\left(\mathrm{R}+\mathrm{P}_{\mathrm{i}}\right) \mathrm{A} @ \mathrm{MOR}$ sample (shown in $\left.\mathrm{SI}-1\right)$. The $\mathrm{N}_{2}$ adsorption/desorption isotherms of the MOR sample showed a steep increase at a low relative pressure at $\mathrm{P} / \mathrm{P}_{0}<0.01$ as a result of filling of the micropores. A hysteresis loop was observed at a high relative pressure range $\left(\mathrm{P} / \mathrm{P}_{0}=0.6-1\right)$ ascribed to the capillary condensation of $\mathrm{N}_{2}$ inside the disordered mesopores. On the other hand, an isotherm characteristic of a non-porous solid (type III) was observed for $\left(\mathrm{R}+\mathrm{P}_{\mathrm{i}}\right) \mathrm{A} @ \mathrm{MOR}$ sample and indicate a complete saturation of MOR micropores. The $\mathrm{S}_{\mathrm{BET}}$ are dropped from 367 to $5 \mathrm{~m}^{2} \mathrm{~g}^{-1}$ and the microporous volume from 0.17 to $0.00 \mathrm{~cm}^{3} \mathrm{~g}^{-1}$. This result suggests a confinement of the building blocks of nucleotides co-adsorbed into the MOR porous space. 
No changes in the X-ray diffraction pattern of the Mordenite prior to and after the chemical reaction were observed (shown in SI-2). Nuclear magnetic resonance $\left({ }^{27} \mathrm{Al}\right.$ MAS NMR) and energy dispersive X-ray spectrometry (EDS) analyses were performed to study the state of aluminum after the chemical reaction. Additionally, the exchange efficiency $\left(\mathrm{Na}^{+} / \mathrm{AH}^{+} / \mathrm{H}^{+}\right)$was studied. ${ }^{27} \mathrm{Al} \mathrm{NMR}$ spectra of $\left(\mathrm{R}+\mathrm{P}_{\mathrm{i}}\right) \mathrm{A} @ \mathrm{MOR}$ samples before and after activation (shown in SI-3) exhibited the same profile with a well-defined signal around $-55 \mathrm{ppm}$ attributed to the tetrahedral framework Al. The absence of any signal around $0 \mathrm{ppm}$ assigned to octahedral aluminum, suggested no dealumination and preservation of the MOR structure after adsorption. EDS analysis confirmed that the $\mathrm{Si} / \mathrm{Al}$ ratio is retained after the chemical reaction. However, the $\mathrm{Na}$ content dropped from $5.5 \%$ in the parent mordenite to $2.6 \%$ in the $\left(\mathrm{R}+\mathrm{P}_{\mathrm{i}}\right) \mathrm{A} @ \mathrm{MOR}$. Based on the adsorbed adenine content $(0.52 \mathrm{mmol} / \mathrm{g} \mathrm{MOR})$, the $60 \%$ replacement of $\mathrm{Na}^{+}$for $\mathrm{H}^{+}$was found. The remaining sodium is most probably situated in the inaccessible small side pockets of the MOR structure. Thus, the accessible large channel contains exclusively acid sites.

To study the condensation reactions of the building blocks to nucleotides, ${ }^{31} \mathrm{P}$ and ${ }^{13} \mathrm{C}$ NMR spectra were employed. Figure 1 shows the ${ }^{31} \mathrm{P}$ NMR spectra of the $\left(\mathrm{R}+\mathrm{P}_{\mathrm{i}}\right) \mathrm{A} @ \mathrm{MOR}$ sample before and after activation at $150^{\circ} \mathrm{C}$ under argon atmosphere.
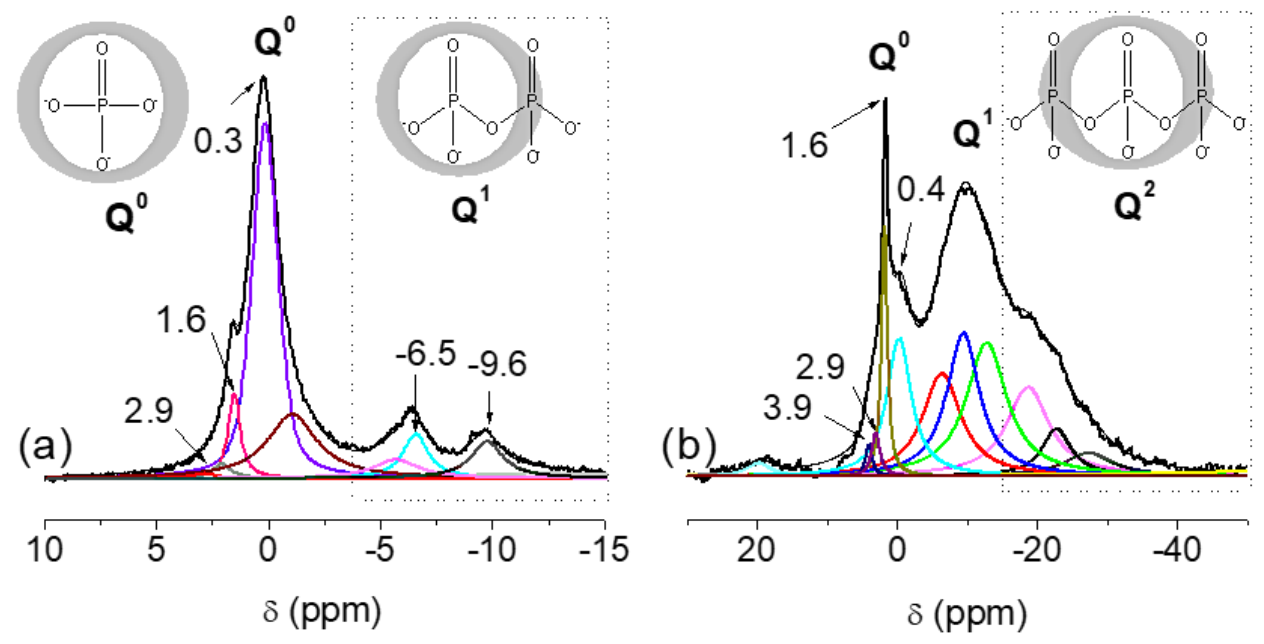
Figure 1. ${ }^{31} \mathrm{P}$ NMR spectra of $\left(\mathrm{R}+\mathrm{P}_{\mathrm{i}}\right) \mathrm{A} @$ MOR samples $(\mathrm{a})$ dried at $50{ }^{\circ} \mathrm{C}$ in air and $(\mathrm{b})$ activated at 150 ${ }^{\circ} \mathrm{C}$ under argon atmosphere.

The sample before activation (Figure 1a) exhibited chemical shifts at 0.3 and 1.6 ppm characteristic of free and adsorbed $\alpha$-phosphates groups $\left(\mathrm{Q}^{0}\right)$ onto the MOR surface, respectively. The Gaussian decomposed weak signal at $2.9 \mathrm{ppm}$ is indicative of the presence of phosphoribosyl group at the $5^{\prime}$ position adsorbed into MOR. The $\mathrm{Q}^{1}$ environments ( $\beta$-phosphates) in the pyrophosphate (PP) region were observed at -6.5 and $-9.6 \mathrm{ppm}$ with close values of the peak area. These signals could be attributed to the $\alpha$ and $\beta$ phosphate groups in the diphosphorylated ribose or PP. They may be also associated to the presence of PRPP which is considered as an intermediate in the synthesis of AMP. ${ }^{22}$ The absence of chemical shifts associated to the polyphosphates environment $\left(\gamma\right.$-phosphates: $\left.Q^{2}\right)$ shows that the ATP molecule cannot be formed at this stage.

The sample after activation (Figure 1-b) exhibited the same $\mathrm{Q}^{0}$ signals at 0.4 and $1.6 \mathrm{ppm}$. A $25 \%$ increase of the signal attributed to the phosphoribosyl groups at $5^{\prime}$ position was observed. In addition, a new $\mathrm{Q}^{0}$ signal that can be associated with a monophosphate in the AMP molecule appeared at 3.9 ppm $(<1 \%)$. The signal around $20 \mathrm{ppm}$ is indicative of the presence of phosphonate groups. The quantity of adsorbed monophosphate prior to and after the activation is about $6.0 \%$. It should be noted that $75 \%$ of the free monophosphate species were consumed, which is coupled with the increase of the $\mathrm{Q}^{1}$ species after activation. Additionally, the new broad chemical shift around -20 ppm suggested the presence of polyphosphates groups $\left(\mathrm{Q}^{2}\right)$. These groups are associated to phosphorylated ribose and/or the presence of ATP.

While the ${ }^{31} \mathrm{P}$ NMR spectra provides information about the condensation of phosphates groups, the ${ }^{13} \mathrm{C}$ NMR spectra (Figure 2) reveals the modifications in the ribose part. 


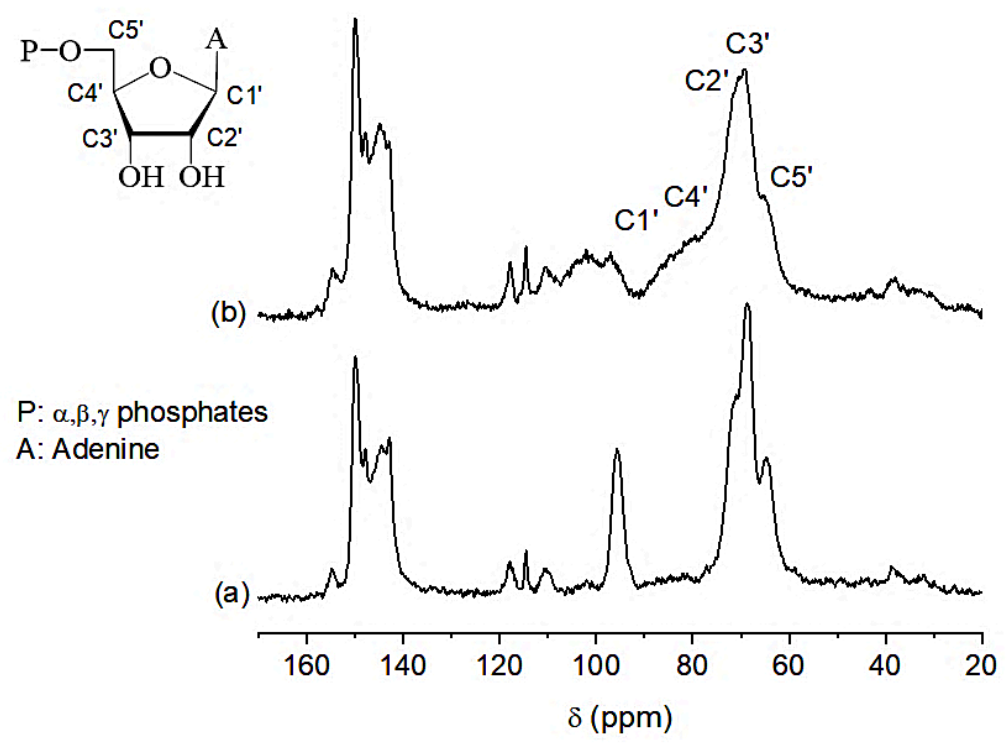

Figure 2. ${ }^{13} \mathrm{C}$ NMR spectra of $\left(\mathrm{R}+\mathrm{P}_{\mathrm{i}}\right) \mathrm{A} @$ MOR samples (a) dried at $50{ }^{\circ} \mathrm{C}$ in air and (b) activated at 150 ${ }^{\circ} \mathrm{C}$ under argon atmosphere.

ACDLab® software was used to assign the carbon groups of ribopyranose ( $\alpha p$ and $\beta p$ ) and ribofuranose ( $\alpha$ f and $\beta f$ ) for bulk D-ribose spectra (shown in SI-4), and AMP, ADP and ATP in the MOR samples. We noticed the absence of $\mathrm{C}^{2}$ ' signals at $56 \mathrm{ppm}$ attributed to bulk ribofuranose in both non-activated and activated samples (Table 1). We relate this result with the substitution in the C5' of ribose that leads to the formation of AMP and ADP. The contributions of ATP appear only in the spectra of activated sample and are in agreement of ${ }^{31} \mathrm{P}$ NMR results. In general, the experimental data show that the increase in temperature plays an important role in the condensation of polyphosphate to ATP. 
(i)

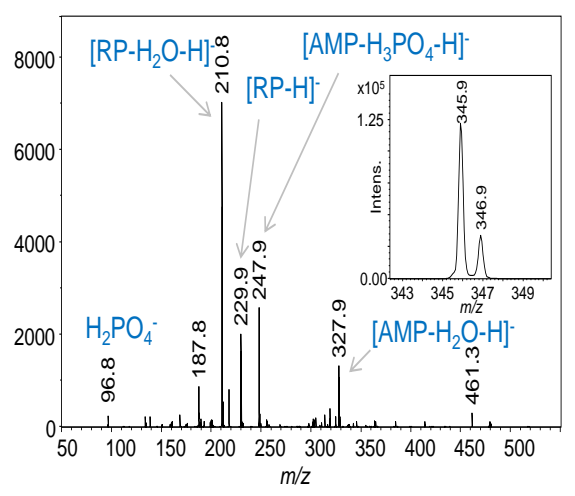

(ii)

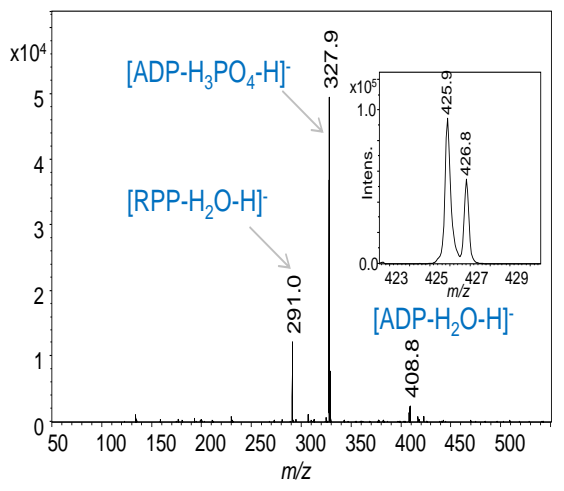

(iii)

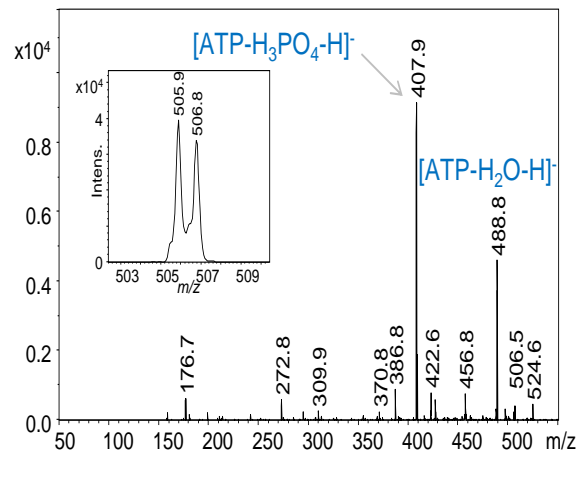

Figure 3. Evidence for AMP, ADP and ATP in thermal activated $\left(\mathrm{R}+\mathrm{P}_{\mathrm{i}}\right) \mathrm{A} @ \mathrm{MOR}$ sample. CID fragmentation mass spectra of $\mathrm{m} / \mathrm{z} 346$ (i), 426 (ii) and 506 (ii). Insets: Mass spectra of isolated precursor ions.

Table 1. ${ }^{13} \mathrm{C}$ NMR chemical shifts of ribose part in AMP, ADP and ATP contributions in the $\left(\mathrm{R}+\mathrm{P}_{\mathrm{i}}\right) \mathrm{A} @ \mathrm{MOR}$ samples before and after thermal activation at $150{ }^{\circ} \mathrm{C}$.

\begin{tabular}{|c|c|c|c|c|c|c|}
\hline \multirow[t]{2}{*}{ Sample } & \multirow[t]{2}{*}{ Form } & \multicolumn{5}{|c|}{ Chemical shift (ppm) } \\
\hline & & $\mathrm{C} 1$ ' & $\mathrm{C} 2$ ' & C3' & C4' & $\mathrm{C} 5{ }^{\prime}$ \\
\hline \multicolumn{7}{|c|}{ Before activation } \\
\hline AMP & $(\alpha, \beta) \mathrm{f}$ & 93.4 & 77.1 & 71.0 & 83.9 & 64.1 \\
\hline ADP & $(\alpha, \beta) f$ & 95.7 & 71.6 & 68.6 & 83.9 & 65.0 \\
\hline ATP & $(\alpha, \beta) \mathrm{f}$ & --- & --- & --- & --- & --- \\
\hline \multicolumn{7}{|c|}{ After activation } \\
\hline AMP & $(\alpha, \beta) f$ & 85.4 & 75.0 & 70.5 & 85.4 & 65.2 \\
\hline ADP & $(\alpha, \beta) \mathrm{f}$ & 85.4 & 71.2 & 69.4 & 80.3 & 66.0 \\
\hline ATP & $(\alpha, \beta) f$ & 97.0 & 71.5 & 70.2 & 84.4 & 65.5 \\
\hline
\end{tabular}


For further confirmation of the presence of nucleotides and the formation of ATP in mordenite pores, MS and MS/MS experiments were performed. Figure 3 shows the spectra for thermally activated samples. The characteristic fragment ions at $\mathrm{m} / \mathrm{z} 211$ and 248 are associated with phosphorylated ribose $\left[\mathrm{RP}-\mathrm{H}_{2} \mathrm{O}-\mathrm{H}\right]^{-}$and $\left[\mathrm{AMP}-\mathrm{H}_{3} \mathrm{PO}_{4}-\mathrm{H}\right]^{-}$, respectively. The peaks at $\mathrm{m} / z 291$ and 328 originate from the diphosphorylated ribose $\left[\mathrm{RPP}-\mathrm{H}_{2} \mathrm{O}-\mathrm{H}\right]^{-}$and $\left[\mathrm{ADP}-\mathrm{H}_{3} \mathrm{PO}_{4}-\mathrm{H}\right]^{-}$species. Finally, the $m / z 408$ and 489 peaks are related to the $\left[\mathrm{ATP}-\mathrm{H}_{3} \mathrm{PO}_{4}-\mathrm{H}\right]^{-}$and $\left[\mathrm{ATP}-\mathrm{H}_{2} \mathrm{O}-\mathrm{H}\right]^{-}$ species. Thus, the set of experimental data unambiguously confirms the presence of ATP. The amount of ATP is probably low since hydrolysis can occur during the desorption process and strong adsorption of ATP can occur on the solid due to its high free energy.

It is known that the condensation reactions to nucleotides from the elemental building blocks are thermodynamically unfavorable. The difficulties in the phosphorylation reactions, named by Orgel 'phosphate problem', ${ }^{7}$ which is a variation of the 'water problem', ${ }^{2-7}$ are also unfavorable for the condensation reactions. The generalized 'water problem' argues that condensation reactions cannot occur extensively in the aqueous solution once hydrolysis takes place and makes these reactions unfavorable. Moreover, the condensation steps from phosphorylation and glycosylation reactions from the building blocks release water, which in turn, is the presumed solvent for most prebiotic reactions. ${ }^{3}$ In this context, prebiotic synthesis of ATP in an aqueous medium is highly unfavorable. Additionally, the high energy required to obtain ATP, led the reactions in the direction of ADP and AMP formation, and it is energetically non-spontaneous in the absence of a catalyst (Eq. 1-2) ${ }^{23-24}$ However, the conversion of ADP into ATP molecules is possible by the foodstuff-oxidation system using enzymes as catalysts as shown in Eq. 3..$^{23-24}$

$$
A T P_{a q}+H_{2} O_{l} \rightleftharpoons A D P_{a q}+P_{i_{a q}} \quad \Delta G^{0}=-32.48 \mathrm{~kJ} \mathrm{~mol}_{(1)}^{-1}
$$


$\left.A D P_{a q}+H_{2} O_{l} \rightleftharpoons A M P_{a q}+P_{i_{a q}} \quad \Delta G^{0}=-32.80 \mathrm{~kJ} \mathrm{~mol}^{-1}\right)^{-1}$

$2 A D P_{a q} \rightleftharpoons A T P_{a q}+A M P_{a q} \quad \Delta G^{0}=-0.31 k \mathrm{~mol}^{-1}(3)$

The synthesis of ATP onto a microporous mineral surface has not been reported to date. Recently, our group demonstrated that dense silica particles catalyze multiple ribose phosphorylation to obtain adenosine monophosphate (AMP). ${ }^{22}$ We proposed the formation of phosphoribosyl pyrophosphate (PRPP) as an activated intermediate in the one-pot synthesis of AMP from their building blocks. The formation of this intermediate was previously described by Perrez Villa et al. ${ }^{25}$ The present experiment shows that the confined mordenite environment helps to overcome the thermodynamic and kinetic limitations, and leads to the formation of AMP, ADP and ATP. The acid sites in the micropore channels are considered the drivers that decrease the overall potential energy barrier and promote the formation of nucleotides. If we assume PRPP as the intermediate to AMP, on an acid MOR catalyst, the possible route of nucleotides formation into the micropores can be proposed as in Eq. 4-7:

$$
\left(R+3 P_{i}\right) H @ M O R=(P R P P) H @ M O R+3 H_{2} 0
$$

$(P R P P+A) H @ M O R=\left(A M P+P P_{i}\right) H @ M O R$

$\left(A M P+P_{i}\right) H @ M O R \rightleftharpoons(A D P) H @ M O R+H_{2} O$

$(2 A D P) H @ M O R \rightleftharpoons(A T P+A M P) H @ M O R$

According to this hypothesis, PRPP is formed first and acts as an intermediate with adsorbed protonated adenine $\left(\mathrm{A}-\mathrm{H}^{+}\right)$in the acid sites of mordenite micropores to protonated AMP (AMP- 
$\mathrm{H}^{+}$). Then, $\mathrm{P}_{\mathrm{i}}$ groups are condensed with $\mathrm{AMP}-\mathrm{H}^{+}$to form $\mathrm{ADP}-\mathrm{H}^{+}$which is partially transformed into ATP- $\mathrm{H}^{+}$, most likely due to dismutation reactions. Additionally, the acid medium $(\mathrm{pH} 2-3)$ and the non-oxidizing dry atmosphere $\left(\mathrm{Ar} / 150{ }^{\circ} \mathrm{C}\right)$ applied in the experiments seems to promote an optimal environment for the chemical reactivity of organic species.

This way, the confined micropore space of the mordenite zeolite and its acid sites may play the key role of promoting the formation of a "prebiotic soup" of ribonucleotides (AMP, ADP and ATP). Additionally, it is the first report of the synthesis of ATP under a porous mineral surface. This high energetic biomolecule is an important source of energy for biological processes and acts as an extremely important co-factor precursor in biology (NADH and coenzyme A).

\section{Experimental Methods}

Adenine (6-Aminopurine; $\geq 99 \%$; CAS 73-24-5), Ribose (D-(-)-Ribose; $\geq 98 \%$; CAS 50-69-1) and potassium phosphate monobasic $\left(\mathrm{KH}_{2} \mathrm{PO} 4 ; \geq 99 \%\right.$; CAS $\left.7778-77-0\right)$ were purchased from Sigma-Aldrich. Parent Na-Mordenite $\left(\mathrm{Si} / \mathrm{Al}=6 ; \mathrm{SBET}=367 \mathrm{~m}^{2} / \mathrm{g}\right)$ was purchased from Zeolyst.

Firstly $32.5 \mu \mathrm{g}$ of adenine (A) was pre-concentrated onto $500 \mathrm{mg}$ of mordenite (MOR) at $\mathrm{pH}$ 2-3. The pre-adsorbed sample was dried at $50{ }^{\circ} \mathrm{C}$ and was designated A@MOR. Then, ribose (R) and monophosphate $\left(\mathrm{P}_{\mathrm{i}}\right)$ were added to the pre-adsorbed sample. Co-adsorption by impregnation with excess of water was applied containing $1.5 \mathrm{~mL}$ of ribose and phosphate solutions with 1 and 2 molar equivalents of adenine, respectively. The sample was dried overnight at $50{ }^{\circ} \mathrm{C}$ in oven under room humidity and was stored in a desiccator before analysis. This sample was designated $\left(\mathrm{R}+\mathrm{P}_{\mathrm{i}}\right) \mathrm{A} @ \mathrm{MOR}$. Thermal activation of samples took place at $150{ }^{\circ} \mathrm{C}$ under argon atmosphere for $2 \mathrm{~h}$. 
Nitrogen adsorption measurements were carried out on a MicromeriticsTriFlex surface area analyzer at $77 \mathrm{~K}$. The samples were analyzed after degassing at $80{ }^{\circ} \mathrm{C}$ for $64 \mathrm{~h}$. The microporous volume $\left(\mathrm{V}_{\text {mic }} / \mathrm{cm}^{3} \mathrm{~g}^{-1}\right)$ and external surface area $\left(\mathrm{S}_{\mathrm{ext}} / \mathrm{m}^{2} \mathrm{~g}^{-1}\right)$ were obtained from t-plot based on the Harkins-Jura equation.

Energy Dispersive Spectroscopy (EDS) analyses were carried out in a Zeiss Sigma 300 SEM equipped with a Bruker Quantax 6030 EDS spectrometer at $20 \mathrm{kV}$ for an acquisition of 500 kcounts. Prior to analyses, each powder sample was dispersed on a stub with a double-sided carbon tape, then was subsequently coated with a carbon layer by evaporation. Semi quantitative results were calculated using a standardless PB-ZAF method.

Solid-state ${ }^{31} \mathrm{P}$ NMR spectra were performed on a Bruker Avance 500 spectrometer using $4 \mathrm{~mm}$ MAS probe and spinning rate of $10 \mathrm{kHz}$ with field of $11.0 \mathrm{~T}$ at room temperature. The major experimental parameters were: simple 1-pulse sequence with a pulse length of $1,25 \mu \mathrm{s}(\pi / 2$ pulse width $3.75 \mu \mathrm{s}$ ), recycle delay of $5 \mathrm{~s}$ and acquisition time of $30 \mathrm{~ms}$. For spectral reference an external standard of phosphoric acid was used setting to $0 \mathrm{ppm} .{ }^{13} \mathrm{C}$ and ${ }^{27} \mathrm{Al}$ MAS NMR spectra were obtained on a Bruker Avance III spectrometer equipped with a $4 \mathrm{~mm}$ H-X MAS probe, operating at frequency of $500.17 \mathrm{MHz}\left({ }^{1} \mathrm{H}\right), 125.77 \mathrm{MHz}\left({ }^{13} \mathrm{C}\right)$ and $130.33 \mathrm{MHZ}\left({ }^{27} \mathrm{Al}\right)$. Chemical shifts were calibrated using the carboxyl signal of adamantane (38.52 ppm) for ${ }^{13} \mathrm{C}$ and $\mathrm{Al}\left(\mathrm{NO}_{3}\right)_{3}$ (0 ppm) for ${ }^{27} \mathrm{Al}$ as external standard. The ${ }^{13} \mathrm{C}$ Cross-Polarization spectra were acquired with a MAS rate of $14 \mathrm{kHz}$, a ramp-CP contact time of $1 \mathrm{~ms}$ and a $1 \mathrm{~s}$ recycle delay and with a ${ }^{1} \mathrm{H}$ decoupling spinal 64.

Mass spectra were acquired on a HCT Ultra PTM Discovery ion trap mass spectrometer (Bruker Daltonics) equipped with an electrospray ion source. Samples were diluted 1/100 in an ionization 
solution of acetonitrile/water 50/50 and analyzed by direct infusion. The nebulizer gas pressure was $11 \mathrm{psi}$ and the spray voltage $3.5 \mathrm{kV}$. The drying gas flow was $5 \mathrm{~L} \mathrm{~min}^{-1}$ and the temperature was $300^{\circ} \mathrm{C}$. Spectra were acquired in negative ion mode over a $50-2000 \mathrm{~m} / \mathrm{z}$ range until the ion charge control target had reached 90,000. The acquisitions were carried out at enhanced resolution $(8100 \mathrm{~m} / \mathrm{z}$ units per second). Collision-induced dissociation (CID) fragmentations were performed on isolated precursor ions using peak width set at 2 Da. External calibration was

performed with the ESI-T Tuning Mix (Agilent Technologies). The instrument was controlled using EsquireControl 6.2 software (Bruker Daltonics) and mass spectra were processed using DataAnalysis 4.0 SP2 software (Bruker Daltonics).

\section{ASSOCIATED CONTENT}

Supporting Information. Electronic Supplementary Information (ESI) are available free of charge:

SI-1. $\mathrm{N}_{2}$ adsorption and desorption isotherms of (a) parent Na-Mordenite and (b) $\left(\mathrm{R}+\mathrm{P}_{\mathrm{i}}\right) \mathrm{A} @ \mathrm{MOR}$.

SI-2. XRD pattern for the bulk mordenite $(M O R)$ and $\left(\mathrm{R}+\mathrm{P}_{\mathrm{i}}\right) \mathrm{A} @ \mathrm{MOR}$ samples before and after activation.

SI-3. ${ }^{27} \mathrm{Al}$ NMR MAS spectra for the bulk mordenite (MOR) and $\left(\mathrm{R}+\mathrm{P}_{\mathrm{i}}\right) \mathrm{A} @ \mathrm{MOR}$ samples before and after activation.

SI-4. ${ }^{13} \mathrm{C}$ CP NMR spectra of bulk ribose (R). 


\section{AUTHOR INFORMATION}

\section{Notes}

The authors declare no competing financial interests.

\section{ACKNOWLEDGMENT}

Dr. F. Rodrigues thanks the Brazilian government for the postdoc scholarship under the CAPES/COFECUB program (Project N 835/15). The authors thank Île-de-France and CNRS for funding.

\section{REFERENCES}

(1) Bean, H. D.; Sheng, Y.; Collins, J. P.; Anet, F. A. L.; Leszczynski, J.; Hud, N. V. Formation of a $\beta$-Pyrimidine Nucleoside by a Free Pyrimidine Base and Ribose in a Plausible Prebiotic Reaction. J. Am. Chem. Soc. 2007, 129 (31), 9556-9557.

(2) Pasek, M. A.; Gull, M.; Herschy, B. Phosphorylation on The Early Earth. Chem. Geol. 2017, 475, 149-170.

(3) Benner, S. A.; Kim, H.-J.; Carrigan, M. A. Asphalt, Water, and the Prebiotic Synthesis of Ribose, Ribonucleosides, and RNA. Acc. Chem. Res. 2012, 45 (12), 2025-2034.

(4) Lohrmann, R.; Orgel, L. E. Urea-Inorganic Phosphate Mixtures as Prebiotic Phosphorylating Agents. Science. 1971, 171 (3970), 490-494.

(5) Reimann, R.; Zubay, G. Nucleoside Phosphorylation: A Feasible Step in the Prebiotic Pathway to RNA. Orig. Life Evol. Biosph. 1999, 29 (3), 229-247.

(6) Šponer, J. E.; Šponer, J.; Fuentes-Cabrera, M. Prebiotic Routes to Nucleosides: A Quantum Chemical Insight into the Energetics of the Multistep Reaction Pathways. Chem.: Eur. J. 2011, 17 (3), 847-854. 
(7) Orgel, L. E. Was RNA the First Genetic Polymer? In Evolutionary Tinkering in Gene Expression, Grunberg-Manago, M.; Clark, B. F. C.; Zachau, H. G., Eds. Springer US: Boston, MA, 1989; pp 215-224.

(8) Oparin, A. I. The Origin of Life. Dover: New York, 1952 (first translation published in 1938).

(9) Bernal, J. D. The Physical Basis of Life. Proc. Phys. Soc., A. 1949, 62 (9), 537.

(10) Jelavic, S.; Tobler, D. J.; Hassenkam, T.; De Yoreo, J. J.; Stipp, S. L. S.; Sand, K. K. Prebiotic RNA Polymerisation: Energetics of Nucleotide Adsorption and Polymerisation on Clay Mineral Surfaces. ChemComm. 2017, 53 (94), 12700-12703.

(11) Joshi, P. C.; Dubey, K.; Aldersley, M. F.; Sausville, M. Clay Catalyzed RNA Synthesis Under Martian Conditions: Application for Mars Return Samples. Biochem. Biophys. Res. Commun. 2015, 462 (2), 99-104.

(12) Aldersley, M. F.; Joshi, P. C. RNA Dimer Synthesis Using Montmorillonite as a Catalyst: The Role of Surface Layer Charge. Appl. Clay Sci. 2013, 83-84, 77-82.

(13) Joshi, P. C.; Aldersley, M. F.; Delano, J. W.; Ferris, J. P. Mechanism of Montmorillonite Catalysis in the Formation of RNA Oligomers. J. Am. Chem. Soc. 2009, 131 (37), 13369-13374.

(14) Ferris, J. P. Montmorillonite-Catalysed Formation of RNA Oligomers: The Possible Role of Catalysis in The Origins of Life. Philos. Trans. Royal Soc. B. 2006, 361 (1474), 1777-1786.

(15) Ferris, J. P. Prebiotic Synthesis on Minerals: Bridging The Prebiotic and RNA Worlds. The Biological bulletin 1999, 196 (3), 311-4.

(16) Mizota, T.; Matsui, K.; Kasai, T.; Nakayama, N. Hydration Enthalpies of Synthetic NaA, Cation-Exchanged-A and Some Natural Zeolites for Evaluating as Heat Exchange Absorbents. Thermochim. Acta 1995, 266, 331-341. 
(17) Ferris, J. P. Mineral Catalysis and Prebiotic Synthesis: Montmorillonite-Catalyzed Formation of RNA. Elements. 2005, 1 (3), 145-149.

(18) Deer, W. A.; Howie, R. A.; Wise, W. S.; Zussman, J. Rock-forming Minerals. Volume 4B: Framework Silicates: Silica Minerals, Feldspathoids and The Zeolites. Geol. Soc., Geological Society Publishing House: Bath, 2004; 982 pp.

(19) Smith, J. V. Biochemical Evolution. I. Polymerization on Internal, Organophilic Silica Surfaces of Dealuminated Zeolites and Feldspars. Proc. Natl. Acad. Sci. U.S.A. 1998, 95 (7), 3370-3375.

(20) Breck, D. W. Zeolite Molecular Sieves: Structure, Chemistry, and Use. 99 ed.; Wiley: New York, 1974.

(21) Tschernich, R. W. Zeolites of the World. Geoscience Press: 1992.

(22) Akouche, M.; Jaber, M.; Maurel, M.-C.; Lambert, J.-F.; Georgelin, T. Phosphoribosyl Pyrophosphate: A Molecular Vestige of the Origin of Life on Minerals. Angew. Chem. 2017, 56 (27), 7920-7923.

(23) Hammes, G. G.; Hammes- Schiffer, S. Appendix 5 Standard Gibbs Energy and Enthalpy Changes for Biochemical Reactions at $298 \mathrm{~K}, 1 \mathrm{~atm}, \mathrm{pH} 7.0, \mathrm{pMg} 3.0$, and 0.25 M Ionic Strength. In Physical Chemistry for the Biological Sciences, 2015; pp 467468.

(24) Papachristodoulou, D.; Snape, A.; Elliott, W. H.; Elliott, D. C. Energy Considerations in Biochemistry. In Biochemistry and Molecular Biology, Oxford: Oxford, 2014; Fifth edition, pp 34-36.

(25) Pérez-Villa, A.; Saitta, A. M.; Georgelin, T.; Lambert, J.-F.; Guyot, F.; Maurel, M.-C.; Pietrucci, F. Synthesis of RNA Nucleotides in Plausible Prebiotic Conditions from ab Initio Computer Simulations. J. Phys. Chem. Lett. 2018, 9 (17), 4981-4987. 